International Journal of Engineering \& Technology, $7(2.29)(2018)$ 1041-1043
International Journal of Engineering \& Technology
SPC
Website: www.sciencepubco.com/index.php/IJET
Research paper

\title{
People's Motives Toward Bone Fracture Alternative Treatment in District of Bandung Barat
}

\author{
Diah Fatma Sjoraida ${ }^{1 *}$, Evi Novianti², Edwin Rizal ${ }^{3}$, Diah Sri Rezeki ${ }^{4}$ \\ ${ }^{1,2,3,4}$ Faculty Of Communication, Padjadjaran University, Bandung \\ *Corresponding Author E-Mail: Diah.Fatma@Unpad.Ac.Id
}

\begin{abstract}
The purpose of this study is to determine the community motive towards an alternative treatment of bone fractures in the district of West Bandung. Today, alternative treatment, especially fracture bone treatment is still popular with the societies, whereas technology and science in the medical world are growing very rapidly. The research method used is qualitative with phenomenology approach. The results of the study show some motives that are the reasons for choosing alternative treatment, among others: [1] Economic motives. The cost of alternative treatment of fractures is fairly cheap because it is not emphasized on a certain amount of cost. [2] Social motives. Believe in the neighbor's experience or experience of the public figures who have done the alternative treatment. [3] Psychological motives. Feel safe and not afraid when doing alternative treatments.
\end{abstract}

Keywords: Alternative Treatment; Motives; Bone Fracture

\section{Introduction}

The development of the medical world is currently growing very rapidly. Many new discoveries in the medical world can treat various diseases. Besides, it is supported also by increasingly sophisticated technology that can provide more solutions to a disease. For example, in the case of minus sight, the solution given in the past used only by wearing eye glasses and improve healthy lifestyle to prevent the eye from worsening. But at this time there is a laser technology, which only in the blink of an eye, an eye with sight problem is back to normal and does not need eye glasses anymore. Another case, namely patients with bone fractures. Various fracture conditions to date can be cured by medical treatment. For example, joints shifted, bone out through the skin, bone cracks, and others condition proven to be cured by advanced technology in the medical world. But, even so, there are still many people who believe in alternative medicine.

In Indonesia, there are known two types of treatment, namely medical treatment and alternative medicine. Medical treatment is usually based on scientific research and in-depth study of a particular disease, whereas alternative medicine is usually based on skills that have been inherited in dealing with a disease. Minister of Health in Ministerial Decree Year 2003 states that alternative medicine is medication and / treatment by way of medication and its treatment refers to experience, inherited skill, and or education or training and applied in accordance with norms prevailing in society. The traditional classical healers are: [: [1] Traditional skill healer [Massage, fracture treatment, circumcision, midwives, reflection, acupressurist, acupuncturist, chiropractor, etc., [2] Traditional healers [herbs, gurah, healers, Shinshe, homeopathy, aroma therapist], [3] Traditional healers with religious approach, [4] traditional supernatural [internal, psychic, psychic, etc.] [HEALTH \& INDONESIA, 2003].

Although medical treatment is growing rapidly, yet alternative medicine cannot be completely abandoned by society. This can be proven by the results of research conducted by the Ministry of Health of the Republic of Indonesia that Indonesia Health Profile Data in 2008, shows the national morbidity rate around $33.24 \%$. Of this number around $65.59 \%$ choose their own treatment [including treatment to the traditional clinic], the rest about $34,41 \%$ choose treatment to health service. This shows that even though modern health services have grown in Indonesia, the number of people who choose traditional medicine is quite high [MoH RI, 2009].

One of the traditional types of treatment that today's society is interested in is the traditional treatment of bone fractures. Preliminary study results in West Bandung, there are at least six traditional treatments which are the bone fractures treatment experts. However, the providers in the six bone treatments experts claimed to have never received any special training to provide such bone treatment. The average handling given in the six traditional medicine experts is the same, usually, the service provider will bind the broken bone with a cloth smeared with a certain oil. There is also a "treat" section of the trauma by simply pulling/ stretching the bone. Actions performed usually depend on the type of bone trauma experienced by the patient. Choosing traditional methods such as fractured bone treatment, is medically still fairly safe, as long as the case is still light or simple [HU Kompas, February 2008]. In addition, the therapist of the fracture treatment is usually getting his skills with hereditary way. In West Bandung regency, precisely at Citapen area, there is some bone fracture clinic that was built along the road and after being traced, it was found that the clinics come from big family. That is, the skills that the therapists have today are the inheritance of their ancestors. The Citapen bone clinic is well known by the community, not only the people around Bandung alone but has expanded to various provinces in Indonesia. Even the injured national athletes are often seen being in traditional treatment at the Citapen bone fracture clinic.

Information about bone fracture clinic is gained from various resources, such as experiences of close friends, advertisements on 
pamphlets, even from family recommendations. This information seeking behavior of alternative medicine will differ between patients with one another. This can happen because of differences in education, work, social, which influenced different motivation. Several studies have shown that motivational factors are very important in determining human behavior in the search for appropriate treatment. The term motivation comes from the word motive that can be interpreted as the strength contained within the individual, which causes the individual to act or do something. The difference in motives with the motivation seen from his condition. Motives are encouragement while motivation is the power that evokes motives. This is similar to what is conveyed by Alex Sobur that motivation means to generate motives, generate power, or move a person/self to do something in order to achieve a satisfaction/goal. [1]. People have different motives when deciding to take alternative or medical treatment. Based on the above background, the authors are interested to conduct a research with the title: Community Motives toward Alternative Bones Fracture Treatment in West Bandung regency. The author wants to find out the motives and reasons people choose alternative medicine compared with medical treatment.

\section{Methodology/Materials}

This research was conducted at Bengkel Tulang [Bone fracture treatment clinics] in Citapen area, West Bandung District. The research design used in this research is observational research using a qualitative method with phenomenology approach. Researchers chose the phenomenology approach in describing the meaning of individual life experiences when performing alternative medicine because this research aims to; [1] describes the life experiences of informants that are interpreted subjectively by themselves [2], and [2] search for the essence of the meaning of experience experienced by individuals [3]. Informants of this study were selected based on the purpose of selecting a sample with rich of information [purposive sampling]. The sampling strategy used is maximum variation sampling that is to obtain variations of various phenomena, identify patterns that are often encountered until no new variation of information is found. This study was conducted to uncover the reasons or motives of patients or families of bone fracture patients when deciding to take alternative treatment.

The data in this study were obtained from primary data sources, namely [1] some patients who experienced problematic bone condition such as, sprains, small fractures or fractures until the bone out through the skin. [2] Secondary data sources obtained from orthopedic physicians or kinds of literature related to this research. The data collection techniques used, namely: [1] Interviews, which is the way used to try to obtain information or the establishment of oral from an informant by way of face to face with several informants related to the research, in this case, is the patient or patient's family who experienced a bone fracture, a therapist or a traditional healer and an orthopedic physician. The number of informants ranging from 6 to 10 is considered sufficient because it has met the methodological requirements for a phenomenological study [4]. Interviews are intensive and intensive and focus on the patient's thoughts, feelings, and actions when deciding on alternative treatments. [2] Documentation, i.e. data collection by viewing and storing documents, archives, pictures or photographs and other secondary data sources relating to research topics and issues. Secondary data is used to support literature study, so as to sharpen the analysis.

\section{Results and Findings}

The results of this research conducted at Citapen bone fracture treatment clinic, District of Bandung Barat is explained through the table below:
Table1: Reasons for Choosing the Alternative Treatment

\begin{tabular}{|c|c|c|c|}
\hline No & Problems & $\begin{array}{l}\text { Alternative } \\
\text { Treatment }\end{array}$ & Medical Treatment \\
\hline 1 & $\begin{array}{l}\text { Sprained } \\
\text { muscle }\end{array}$ & $\begin{array}{l}\text { Cheap be- } \\
\text { cause there is } \\
\text { no certain } \\
\text { price for } \\
\text { certain treat- } \\
\text { ment }\end{array}$ & $\begin{array}{l}\text { Taking too long procedure, such } \\
\text { as first examination, x-ray, re- } \\
\text { examination and complicated } \\
\text { treatment [operation, cannot } \\
\text { move for a long time] and expen- } \\
\text { sive. }\end{array}$ \\
\hline 2 & $\begin{array}{l}\text { Broken arm } \\
\text { [bone } \\
\text { through } \\
\text { skin] } \\
\text { caused by } \\
\text { motorcycle } \\
\text { accident }\end{array}$ & Quick healing & Take a long time to heal. \\
\hline 3 & $\begin{array}{l}\text { Broken leg } \\
\text { caused by } \\
\text { motorcycle } \\
\text { accident }\end{array}$ & $\begin{array}{l}\text { Quick healing } \\
\text { and cheap }\end{array}$ & $\begin{array}{l}\text { Expensive and take along time to } \\
\text { heal }\end{array}$ \\
\hline 4 & $\begin{array}{l}\text { Broken } \\
\text { elbow } \\
\text { caused by } \\
\text { fallen from } \\
\text { stairs }\end{array}$ & $\begin{array}{l}\text { Experienced } \\
\text { therapist }\end{array}$ & $\begin{array}{l}\text { Avoiding hospital complicated } \\
\text { administration }\end{array}$ \\
\hline 5 & $\begin{array}{l}\text { Broken } \\
\text { ankle } \\
\text { caused by } \\
\text { motorcycle } \\
\text { accident }\end{array}$ & $\begin{array}{l}\text { The therapist } \\
\text { was a family } \\
\text { member }\end{array}$ & Worried of doctor's malpractice \\
\hline 6 & $\begin{array}{l}\text { Broken arm } \\
\text { [bone } \\
\text { through } \\
\text { skin] } \\
\text { caused by } \\
\text { motorcycle } \\
\text { accident }\end{array}$ & $\begin{array}{l}\text { Healed by } \\
\text { three times } \\
\text { treatment and } \\
\text { the victim } \\
\text { was happy for } \\
\text { no pain expe- } \\
\text { rienced }\end{array}$ & $\begin{array}{l}\text { The victim was afraid of hospital } \\
\text { treatment }\end{array}$ \\
\hline
\end{tabular}

Respondents 1 prefer alternative treatment because it is cheap and not emphasized at a certain cost. The process of financing alternative medicine is not subject to tariffs, so as not to burden the patient. The range of money spent on a therapist is Rp. 30.000,00 to Rp. 100.000,00 whereas medical treatment in Hospital must go through a long procedure such as initial inspection, x-ray, reexamination and complicated handling [pen installation, opening, and closing stitches] and it all cost not less. Hospital financing tends to be expensive because it requires a lot of tools, medicines and proper handling by specialist doctors, especially physiotherapy. The Economic factor is the reason for respondent 1 in choosing an alternative treatment. According to Dr. Muki Partono, Sp.OT said that the total cost of the patient if going to alternative medicine and to the orthopedics is not much different. An example of a case of a manager who worked at UNILEVER at the time if he did not follow his elder sister who advocated alternative medicine may be he is still working, had not to pay for anything, and not disabled. The manager went to alternative medicine for 8 months with total cost Rp.14.860.000,00. So, in that case, it is not true to say to go to an alternative treatment is cheaper than to the orthopedic. Finally, the manager was laid off because it had been given 6 months still cannot work, and doctors were not able to help much because the bone condition was not able to connect. [5] Economic factors and factors of convenience that the reason the respondent chose an alternative treatment.

Unlike the reasons were given by previous respondents, social factors are the main reason respondents 2 chose alternative medicine. Based on the experience of neighbors who have had an alternative treatment that the rapid cure is not protracted as in the Hospital. However, the condition experienced by the respondent until now has not felt better healing or change because according to the therapist the treatment process is still long and cannot heal only with one visit. Respondents are still hopeful and optimistic he will heal in the hands of alternative therapists.

Respondent 3 has the same reasons as respondents 1 and 2, namely economic and social factors. Respondents prefer alternative treatment in addition to the low price, it was also healing quickly. In contrast to the conditions experienced by respondents 2 , re- 
spondents 3 only visited the place of traditional treatment once and immediately healed, but the therapist suggested to come again in order to check the development of his legs. The incidence is the same as that experienced by a patient who has a child with a fracture condition and then treated traditionally and declared as cured. But the parents took the initiative to do a check up to the hospital, and the fact that there is still swelling in the right upper knee area and a little pain. There is a knee slide movement towards the front In the X-ray, there appear to be fractures and a shift towards the front of the epiphyte plate portion of the end of the thigh bone. In the future, there is a chance of right thigh going shorter than the left thigh. There is also the possibility of right knee bent into the form of the letter O. Currently the patient does not complain about the process that is happening on his knee. However, with the course of the process of degeneration due to abnormal biomechanics of the knee will threaten the occurrence of early osteoarthritis. Respondent 4 also did alternative treatment because social factors such as based on neighbor experiences and respondents know that the therapist is very experienced in handling cases of fractures Respondents often hear that injured sports athletes seek treatment for these alternative treatments. In addition, respondents avoid complicated procedures if they have to go to the hospital. Unfortunately, respondents cannot recover as usual because of the late handling of their parents. In fact, these respondents have tried an alternative treatment to four different therapists.

A plausible reason was put forward by respondent 5 who stated that the therapist was a member of his family, as his grandfather so he believed more if handled by his own family. The respondents also have excessive care for handling by doctors at the hospital. As disclosed by Dr. Muki Partono, Sp.OT that rumors in the community that bone operation always cut the bone or if drugged will not wake up again, is not true because at this time the drugs are safe, and instead there are techniques of anesthesia that keep people aware during surgery, even currently developing surgical techniques whose incisions are small operations and are commonly called MIS [Minimally Invasive Surgery]. [5]. Psychological factors are the reasons respondents chose alternative medicine. Respondents feel more trust and safer handled by their own grandfather rather than having to go to the hospital.

Respondent 6 stated the reasons for choosing alternative treatment compared to the hospital is that patients feel happy because the process of handling caused no pain. Patients feel afraid to seek treatment at the hospital because of the growing rumors that if the fracture should be surgery and difficult to recover. Psychological factors that affect patients in deciding to seek treatment to alternative medicine. Conditions experienced by these respondents also recovered after treatment for 3 times to an alternative therapist. This is because the process of grafting bone fractures in children is better than adults because the bone wrapping layer is still thick, better bleeding, better remodeling power [which is not owned in the bone grafting process in adults], this is what makes children Easier to connect and the result is good whoever handles it. [5]. Each respondent has different motives depending on the characteristics of the respondent. The motives that affect the behavior of respondents in doing alternative medicine, among others:

\section{Economic motive:}

The cost of alternative treatment of fractures is fairly cheap because it is not emphasized on a certain amount of cost. Unlike the case with the financing in the hospital, which requires more expensive fees because the procedure to be done was more complicated. Looking at the characteristics of respondents who have a weak economic situation, then alternative medicine is the only solution that can be taken.

\section{Social motives.}

Respondents believed more about neighbors' experiences of alternative treatment, rather than medical treatment at the hospital. In addition, many respondents also saw the famous national athletes seek treatment for these alternatives. Respondents became increasingly convinced that their choice of treatment to alternative medicine was the right choice.

\section{Psychological motives:}

One respondent believed that his broken bone was handled by his own family. Given that the therapist who will perform treatment is his grandfather, it raises a sense of security towards the respondent In addition, these respondents also have excessive care for handling by doctors at the Hospital. Other respondents said they prefer alternative treatment compared to hospitals i.e. patients feel happy because the process of handling caused no pain. Rumors about surgery or amputations performed by the hospital also further exacerbate the level of confidence of respondents to medical treatment.

Trust and confidence in a treatment action are important because it can help the healing process quickly. This is something that most people do not realize its importance for medical treatment, so people with a sense of dissatisfaction with the medical switch to alternative medicine. In addition, seeing the fact that medical treatment has not succeeded in convincing people in dealing with cancer, hypertension, diabetes, and others has resulted in a reduced level of public confidence in medical treatments known to be high cost.

\section{Conclusion}

Based on the results of exposure, it can be concluded that there are some community motives in deciding to choose bone fractures alternative treatment, those are [1] Economic motives. The cost of alternative treatment of fractures is fairly cheap because it is not emphasized on a certain amount of cost. [2] Social motives. Hear the success of neighbors or public figures who have done alternative treatment. [3] Psychological motives. Feel safe and not afraid when doing alternative treatments. Basically, doing alternative or medical treatment has advantages and disadvantages of each.

\section{References}

[1] Alex S. Psikologi umum, CV. PUSTAKA SETIA, Bandung. 2009

[2] Taylor C. Multiculturalism: Princeton University Press; 1994.

[3] Drew RA. The tropical fruit flies [Diptera: Tephritidae: Dacinae] of the Australasian and Oceanian regions. Memoirs of the Queensland Museum. 1989;26.

[4] Creswell JW. Research design: Qualitative \& quantitative approaches: Sage Publications, Inc; 1994.

[5] Partono M. Osteoporosis Fraktur Vertebra Sebagai Salah satu Faktor Resiko Nyeri Pinggang. 